\title{
A College President and the Standards For College Libraries
}

\author{
By JAMES S. COLES
}

$\mathrm{J}$

UST WHAT a college president can say about libraries or library standards which will be new to librarians is problematical. Carlyle said it all in referring to the true university as a collection of books. I cannot help but think of Stephen Leacock, who had that happy facility to put things in their proper order: "If I were founding a university I would found first a smoking room; then when I had a little more money in hand, I would found a dormitory; then after that, or more probably with it, a decent reading room and a library. After that, if I still had more money that I could use, I would hire a professor and get some textbooks."

Leacock was a prophet, making Carlyle's True University into the Modern College, for what library now gets along without a smoking room, and in what library browsing room are students not found dormant with their feet on chairs, with shoes decorously removed to avoid scarring the upholstery? And what librarian does not sometimes wish that the college president hired only one professor?

The ALA Standards for College Libraries are familiar to me because Bowdoin carefully reviewed its library with respect to them as soon as they were publicized. In the general mailing to all college presidents I had received an early copy of the Standards and had immediately studied it, so that by the time Kenneth Boyer, the Bowdoin librarian, adroitly slipped a copy in a letter on a somewhat related topic, I could tell him that "I was, of course, already familiar with it." Subsequently we reviewed these
Mr. Coles is president of Bowdoin College, Brunswick, Me. This address was delivered at the meeting of ACRL's College Libraries Section in Montreal, June 21, 1960.

standards carefully with respect to the operation of the Bowdoin College Library, both in the Faculty Committee on the Library and the Committee of the Governing Boards concerned with the library.

The Standards represent an excellent report and have already proved extremely helpful to many colleges and many college presidents. They serve as fine guideposts. With given standards, colleges can weigh themselves and improve their programs. For librarians who deal with an unsympathetic administration, they may take them off a reducing diet.

There is little that can be said in either constructive or destructive criticism of these standards. They were drawn by experts, and have been reviewed, discussed, criticized, and edited by hundreds more experts from every point of view. Dr. Felix E. Hirsch and his committee have recognized that many excellent libraries may be deficient compared with one or more of the individual standards, according to the particular situation or because of special circumstances. But they do represent a sound, basic yardstick - a needed yardstick.

There are two things, however, that I would emphasize about the Standards: one, that they are minimum standards; two, that they are standards for the present, rather than for the future. With the rapid changes which are taking place 
in so many ways, these standards should be continually reviewed and revised.

Another important philosophy which I think is properly emphasized by these standards is the concept of librarians as educators. They are very much educators, not only with respect to the college student, but with respect to college faculties, officers of administration, and college governing boards. As educators they must not only teach these various publics the purpose and functions, the facilities and resources, of their respective libraries, but they must also remain acutely aware of new developments in library science. They will, in addition, preferably be doing some experimentation and research on their own.

But at this particular juncture in the development of higher education, there is another aspect of this concept of librarians as educators which should not be overlooked. The efficiency of the teaching process and the classroom teacher is presently under close scrutiny, and many programs are under way whereby it is hoped this efficiency will be increased. The purpose of this is, of course, two-fold: one, as a means of ameliorating the shortage of teachers; and two, as a means of effecting economies which will make possible increase in individual faculty salaries. This same scrutiny must apply to librarians as educators.

Like the professor, librarians should operate at their highest level of training and competence during the hours of their working day. Librarians-and now I speak in terms of the smaller college with reference to the librarian, and in the larger university an analogous divisional librarian-the librarian should no more spend his time on clerical and secretarial work than should the professor. As colleges provide more assistance to the professor so that he may devote more of his time to his teaching, his research, and his students, so must this same type of assistance be provided and used by the librarian. Too many colleges and too many college presidents fail to recognize the librarian as a professional, and $I$ fear that there are some librarians who themselves can be similarly criticized. One imaginative, trained librarian with good administrative ability, can, through careful selection and training of his staff, multiply several-fold the contribution he alone could make to the intellectual life of an institution.

One can't assume that libraries are not without their headaches for the college president.

The college president likes libraries. He likes the library in his college. He recognizes its value. He recognizes also its problems and its needs and sees many ways in which it can serve the institution to better advantage. At the same time he cannot avoid thinking of the standard 5 per cent. (How smart Dr. Hirsch and his committee were to establish library costs in terms of a percentage of total budget. Our Canadian friends won't appreciate this, but certainly we Americans from a "soft currency area" have inflation with us and are acutely aware of these facts.)

But the college president knows his institution is short of money, and it is short of space because it has no money; it is short of professors because it is short of money, and if it did have money, would not have the space in which to put them. The library is also short of space, and equally short of books, but it wouldn't do the average library much good to have more books, because it is short of space. And so on through the various departments of the average college.

The statistics with respect to library costs are known to all of you, but on the off-chance that some uninformed college president might have his $\mathrm{U}-2$ focussed on us down here, and for his benefit, it has been estimated that to order, search, handle, classify, bind, shelve, and maintain a purchase book costs $\$ 10$, or for a 


\begin{tabular}{ccccc}
\hline \hline $\begin{array}{c}\text { Academic } \\
\text { Year }\end{array}$ & $\begin{array}{c}\text { Library } \\
\text { Operating } \\
\text { Expense } \$\end{array}$ & $\begin{array}{c}\text { Library } \\
\text { Operating } \\
\text { Expense per } \\
\text { Student }\end{array}$ & $\begin{array}{c}\text { Library Operating } \\
\text { Expense per student } \\
\text { Adjusted to the } \\
\text { 1937-39 Dollar* }\end{array}$ & $\begin{array}{c}\text { Percentage of } \\
\text { Library Operating } \\
\text { Expense to Total } \\
\text { Operating Expense* }\end{array}$ \\
\hline $1946-47$ & $\$ 42,186$ & $\$ 44$ & $\$ 34$ & $4.6 \%$ \\
$1947-48$ & 50,723 & 48 & 35 & 5.0 \\
$1948-49$ & 51,753 & 54 & 34 & 5.0 \\
$1949-50$ & 55,164 & 62 & 36 & 5.6 \\
$1950-51$ & 52.492 & 65 & 37 & 5.0 \\
$1951-52$ & 52,566 & 68 & 38 & 5.1 \\
$1952-53$ & 56,187 & 74 & 40 & 4.9 \\
$1953-54$ & 57,230 & 76 & 40 & 4.7 \\
$1954-55$ & 57,928 & 78 & 40 & 4.3 \\
$1955-56$ & 59,091 & 77 & 42 & 4.5 \\
$1956-57$ & 63,954 & 80 & 46 & 4.8 \\
$1957-58$ & 65,785 & 86 & 49 & 5 \\
$1958-59$ & 76,102 & 97 & 52 & \\
$1959-60$ (Est) & 81,121 & 104 & 54 & \\
$1960-61$ (Est) & 90,099 & 111 & & \\
\hline
\end{tabular}

* Total operating expense has been adjusted to exclude the expenditures of auxiliary enterprises and financial aid to students.

** Adjusted to the purchasing power of the 1937-39 dollar.

periodical, $\$ 20 .{ }^{1}$ In 1958 the average purchase price of a volume was $\$ 6.17 .^{2}$

At Bowdoin last year, taking total library costs on a unit volume basis, one finds that the $30 \phi$ per volume per year in library costs resulting would require $\$ 8$ provided per year in endowed funds. This figure would include servicing the entire library, and the cost for nominal growth merely to maintain the quality of the collections.

If we add five thousand volumes per year, proportionately we should add $\$ 40,000$ per year to the endowment for the library, if service and rate of growth are to remain proportional.

Librarians will have to be alert to sources of support, and cultivate them.

Librarians must not only be educators but they must also have an acute sense to combine statistical cost data and public

1 Columbia University. President's Committee on the Educational Future of the University. Subcommittee on the University Libraries, Columbia University Libraries; a Report on Present and Future Needs Prepared by the Subcommittee; Maurice F. Tauber, Chairman. (Columbia University. Studies in Library Service, No. 9) (New York: Columbia University Press, 1958), p. 197.

2 "Analysis of All Economic Books Listed in Publisher's Weekly Record Section)," Library Journal, LXXXIV (1959), 1940; William H. Kurth, "U. S, Book and Periodical Prices-A Preliminary Report," Library Journal, LXXXV (1960), 55. relations. For example, at Bowdoin, the average cost to have a book rebound is $\$ 2.52$, and to have a periodical bound is $\$ 4.67$. Yet, when the library purchased a book cart to catch returned books so designed to reduce wear and tear on bindings and thus reduce the number of volumes requiring rebinding in a given year, a great hue and cry was raised by people who should have known better that this money was being wasted. Good book carts of this type are not cheap, but a little simple arithmetic demonstrates they easily pay for themselves many times over in the savings which result from reduction of wear. This was the message which did not "get across" and which could easily have avoided much criticism of the library, to say nothing of wasted time by students and faculty, and wasted space in the "Letters to the Editor" column of the undergraduate newspaper!

You might be interested in how costs have changed in the library of a small college which does maintain a research collection-the total library approximating a quarter million volumes. These are shown in the table, which covers the years from 1946 through to the projec- 
tions for the next fiscal year. (The figures for the current year are not final, but after the books are closed will not be markedly different.)

Note especially that the figure for total operating expense excludes expenditures for auxiliary enterprises and for financial aid to students. Often this is not done, but in order to make these comparisons valid it is necessary. For example, in the early 1950's Bowdoin appropriated practically no monies from general funds for financial aid to students. In 1953-54 in order to meet rising costs, tuition was increased $\$ 200$ annually. So as not to exclude students of limited financial means, it became necessary to provide more funds for financial aid-funds beyond those available from endowed scholarships and gifts. This necessitated the appropriation of approximately $\$ 60$ per student from the increased tuition directly back into student aid, meaning that the net increased budget with the tuition jump was but $\$ 140$ per student. Subsequent increases in tuition have required subsequent additional appropriations from general funds into scholarships. This is not real income to the college, nor a real expense, but is more in the nature of a rebate on tuition. Increased income entered once as tuition receipts cannot be entered in duplicate as financial aid. Similar arguments obtain with respect to auxiliary enterprises which operate on a closed book basis, showing no profit or no loss to the college, and washing out income against expense.

Without any particular intent, Bowdoin seems to have been hovering around the "magic number." In recent years, it has dropped below the 5 per cent level, but this decrease has taken place simultaneously with the very determined effort on the part of the college to increase faculty compensation markedly, and to avoid any deferred maintenance with respect to the college plant.

Note also that in terms of "constant" 1939-40 dollars, there has been a gradual increase in real costs of library operation. I believe this can reasonably be ascribed to changes in the nature of undergraduate instruction, requiring more independent work, and in the increased amount of research undertaken by the faculty.

The college president recognizes the value of the library in bringing students into contact with books, and thus into contact with all of human culture and, more important, in permitting the student the joy of discovery which he can never find more easily and more delightfully than in picking some "undiscovered" book off the shelf. The college president also recognizes the necessity of a good library for good scholarship and in order to maintain the research activity of the faculty, so essential to its continuing liveliness.

It is rarely pointed out, however, that these two functions are really quite different. The first, in bringing students into contact with books and all the pleasures and advantages that accompany them, is possibly more akin to the function of a public library, albeit on a, perhaps, more sophisticated level. There is also the associated function of providing material supplementary to textbooks, classes, and lectures, through reserve shelves, etc.

The second function, however, involves the classification and indexing, the storage, and the means of quick random access, of information of all types. Perhaps this analysis is somewhat colored by my own research training as a chemist, with the high degree of organization of chemical literature and the type of information which chemists ordinarily seek in literature. But in general this analysis should hold pretty well for most fields.

A system of classification and indexing and the storage and the quick random access of information in many ways is closely akin to modern banking -so much so that I wonder if the librarian might (Continued on page 296)

COLLEGE AND RESEARCH LIBRARIES 


\section{A College President and the Standards}

(Continued from page 270)

not look toward the banker-not for philanthropy as he has in the past, but for ideas and suggestions with respect to the classification, indexing, storage and quick random access to information. Today's banker handles very little money. One bank president with whom I discussed this told me that while his bank has assets approaching one hundred million dollars, they scarcely ever have more than $\$ 200,000$ or $\$ 300,000$ on hand in cash. What the banker does do, however, is to handle information of all types, information with respect to depositors' or borrowers' names, accounts, type of accounts, additions or subtractions from those accounts, interest credits to or charges against those accounts, credit risks, reliability of securities, etc. As this information is received by the bank, it must be classified according to type of service, indexed, stored, and then upon a moment's notice, the banker must be able to go to any particular bit of information and know that he has it completely and accurately.

The modern banker is now turning to computing machines with magnetic memory systems to fulfill this particular function. Perhaps the librarian of the future, in fulfilling his function as the custodian of information, will also do it in gigantic machines with magnetic memories.

Old-school librarians frequently were attracted to their careers because of their love of books. In the functional sense, however, the new librarian must choose his career on other grounds. Some of you revolt at this, and as a bibliophile, I cannot say that I blame you. However, as those of you who are familiar with the chemical literature know, even in a single field which has been as well organized as it can be, old methods have already shown themselves to be unable to cope with the tremendous growth of knowledge and information.

Not only in the sciences, but even in the humanities, there is already activity of this sort. One need only cite the "holy alliance" of IBM and the Vatican in preparing the concordance for the Dead Sea Scrolls by means of the IBM 604-B computer in but a minute fraction of the decades which would have been required for scholars working with pencil, paper, and index cards.

Librarians have experimented, and will continue to do so. The browsing rooms introduced during the last generation represent an attempt to bring students into close contact with books, and the new library design of commingled reader space and stack space is a further attempt to meet this same problem, as part of the imagination which must be used in order that the second function may be properly fulfilled.

In reassessing the implementation of the ALA Standards for College Libraries, I would only emphasize once again that these are standards for the present rather than standards for the future. They are representative of the average rather than the progressive.

\section{Medal Awarded Metcalf}

At the fiftieth anniversary convocation of the dedication of the central building of the New York Public Library a medal of honor for an outstanding research librarian was presented to Keyes D. Metcalf, librarian emeritus, Harvard College Library. Representative presentations were also made to the Library of Congress, the British Museum, and the Bibliotheque National. 